\title{
PROCESSING OF WADI QENA KAOLINITIC WHITE SANDS BY SELECTIVE DISPERSION AND LEACHING FOR INDUSTRIAL USES
}

\author{
M. A. EL Sayed ${ }^{1}$, W. M. Fathy ${ }^{1]}$, A. M. Salleh, ${ }^{1}$ S. S. Ibrahim ${ }^{2}$ and M. R. Moharam ${ }^{1}$ \\ ${ }^{1}$ Mining and Petroleum Dept., Faculty of Eng., Al-Azhar University., Nasr City, Cairo, Egypt \\ ${ }^{2}$ Central Metallurgical Researches and Development Institute (CMRDI), Cairo, Egypt
}

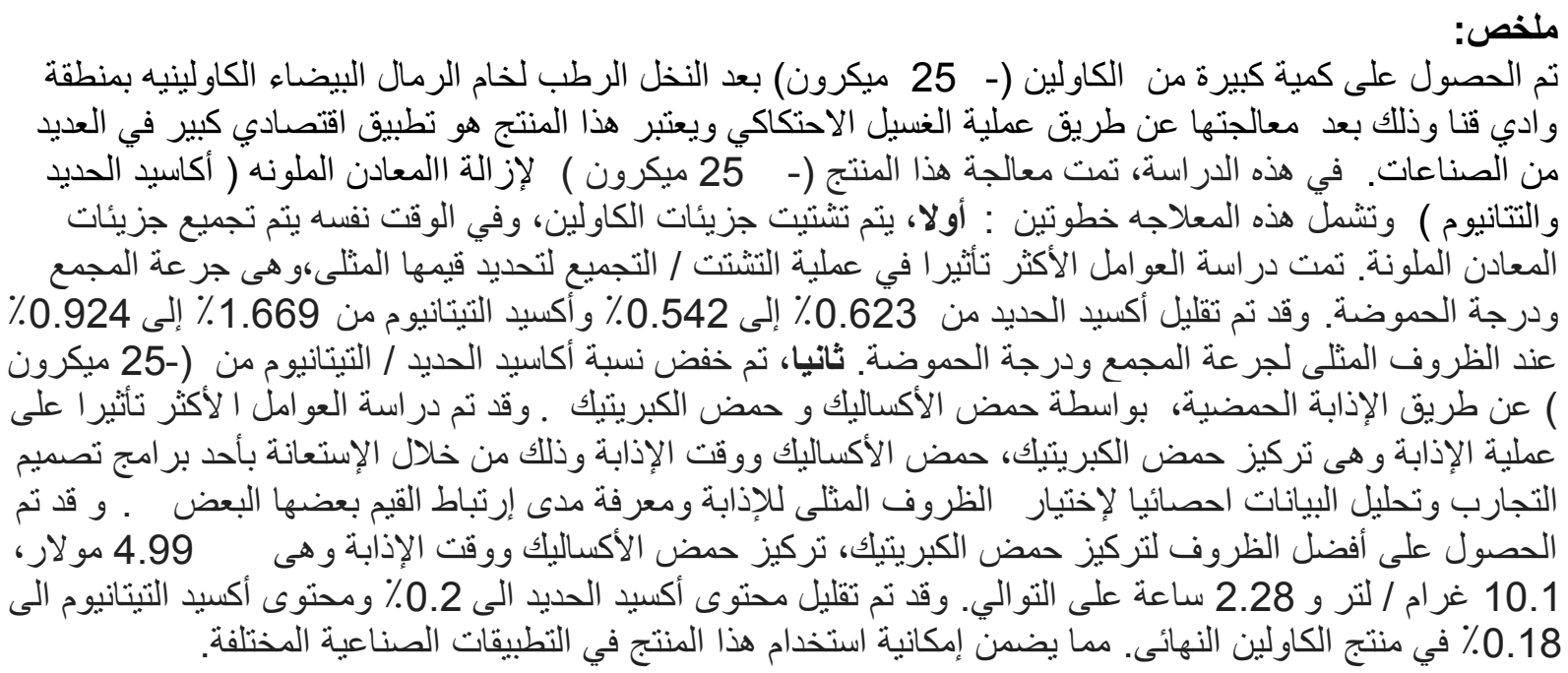

\begin{abstract}
A considerable amount of $-25 \mu \mathrm{m}$ kaolin was obtained during the processing of wadi-Qena kaolinitic white sands by attrition scrubbing. This kaolin product is obtained by desliming the kaolinitic white sand. Such product is of a great economic application in many industries. In this study, this product ($25 \mu \mathrm{m}$ kaolin) was treated or beneficiated to remove colored minerals, (iron / Titanium oxides). The treatment includes two steps. First, the kaolin particles are dispersed and at the same time the colored mineral particles are flocculated. The most affecting parameters in dispersion/flocculation process, flocculant dosage and $\mathrm{pH}$ are investigated to select its optimum values. In this step and under optimum conditions of flocculant dosage and $\mathrm{pH}$, it was possible to decrease iron oxide from $0.623 \%$ to $0.542 \%$ and titanium oxide from $1.669 \%$ to $0.924 \%$. Second, it was attempted to further decrease iron/titanium oxides of $-25 \mu \mathrm{m}$ kaolin by acidic leaching, oxalic acid followed by sulfuric acid. The most affecting parameters which include sulfuric acid concentration, oxalic acid concentration and leaching time. The response surface methodology (RSM) coupled with Box- Behnken design (BBD) and analyses of variance (ANOVA) were performed to optimize the leaching process and determine the main and interaction effects. The response factors were taken as iron oxide content and titanium oxide content. In this context, it was found that the second order polynomial regression model is satisfactory as the predicted responses showed a good agreement with the experimental data. The optimum conditions for sulfuric acid concentration, oxalic acid concentration and leaching time were found as 4.99 molar, $10.1 \mathrm{~g} / \mathrm{l}$ and $2.28 \mathrm{hr}$. respectively. Under these experimental conditions, the iron oxide content and titanium oxide content in kaolin product approached $0.2 \%$ and $0.18 \%$ respectively. Which assures the possibility of using such product in different industrial applications.
\end{abstract}


Key words: White sand, kaolin, attrition scrubbing, flotation, Disperse/Flocculation, polyacrylamide, leaching, sulfuric acid, oxalic acid.

\section{INTRODUCTION}

Kaolin (hydrated aluminum silicate, $\mathrm{Al}_{2} \mathrm{Si}_{2} \mathrm{O}_{5}(\mathrm{OH})_{4}$ ), is an industrial clay of important economic benefit. Its fine particle size, platy shape, inertness, non-toxicity, as well as high brightness and whiteness make it a more versatile mineral, with applications in a wide variety of industries. Commercial kaolin resources are found as sedimentary deposits and as weathering or hydrothermal alteration product of rocks containing a high proportion of alumino-silicate minerals [1]. Crude kaolin ore deposits are contained in a variety of Kaolinitic rock types. Primary kaolin generally describes a kaolin ore altered from an igneous or metamorphic rock that was kaolinized in situ by hydrothermal or weathering processes [2]. Kaolin is considered an important industrial mineral because of its excellent firing properties and relatively high melting point. Its major application or use is often extended to include paint, ceramic, rubber and paper industries. In the paint industry, kaolin is used very extensively in water-based paint system as a functional extended pigment with moisture content exceeding $1 \%$. Resistivity test using the conductivity bridge gives an indication of residual soluble salts in paints due to the presence of kaolin. In the rubber industry, kaolin is used because of its reinforcing and stiffening properties. Fine kaolin gives good resistance to abrasion. There are some tests based on properties of kaolin that are to be conducted before using it for the manufacturing of rubber. They include water setting characteristics, oil absorption, stress/strain, tear resistance, abrasion resistance, heat generation, energy rebound, extrusion and plasticity, hardness, aging characteristics, water absorption and free moisture [3]. Kaolin also is chemically inert over a relatively wide $\mathrm{pH}$ range, white in color and has good covering power when used as a pigment or extender. It is soft, nonabrasive and has a low conductivity of heat and electricity. Some uses of kaolin, such as in paper coating, or as fillers in paints and plastics require very rigid specifications including particle size, color and brightness and viscosity. There are other kaolin uses require no specifications where the chemical composition is most important such as in cement industry. The paper industry consumes the largest amount of kaolin where it is used both as filler and as a coating material on the paper surface to improve the quality of printing [4].There are basically two ways for removing titanium impurities by selective dispersion / flocculation: i) disperse kaolin in a water suspension, flocculate the $\mathrm{TiO} 2$ impurities and separate them by sedimentation and ii) disperse kaolin in a water suspension, flocculate the kaolinite, keep impurities in suspension and separate them by sedimentation[5].The use of organic acids has been very efficient for the whitening of kaolin. The effectiveness of several organic acids (sulfuric acid with oxalic acid or critic acid) to dissolve iron from iron compounds was evaluated. Sulfuric acid with oxalic acid was found the most promising because of its acid strength, good complexing characteristics and high reducing power, compared to other organic acids [6]. Leaching of iron oxides with oxalic acid takes place via the following equations [7, 8].

$$
\begin{aligned}
& \mathrm{Fe}_{2} \mathrm{O}_{3}+6 \mathrm{H}_{2} \mathrm{C}_{2} \mathrm{O}_{4} \rightarrow 2 \mathrm{FeO}\left(\mathrm{C}_{2} \mathrm{O}_{4}\right)_{3}^{-3}+6 \mathrm{H}^{+}+3 \mathrm{H}_{2} \mathrm{O} \\
& 2 \mathrm{FeO}\left(\mathrm{C}_{2} \mathrm{O}_{4}\right)_{3}^{-3}+6 \mathrm{H}^{+}+3 \mathrm{H}_{2} \mathrm{O} \rightarrow 2 \mathrm{FeC}_{2} \mathrm{O}_{4} \cdot 2 \mathrm{H}_{2} \mathrm{O}+3 \mathrm{H}_{2} \mathrm{C}_{2} \mathrm{O}_{4}+2 \mathrm{CO}_{2} \\
& \mathrm{Fe}_{2} \mathrm{O}_{3}+3 \mathrm{H}_{2} \mathrm{C}_{2} \mathrm{O}_{4}+\mathrm{H}_{2} \mathrm{O} \rightarrow 2 \mathrm{FeC}_{2} \mathrm{O}_{4} \cdot 2 \mathrm{H}_{2} \mathrm{O}+2 \mathrm{CO}_{2}
\end{aligned}
$$

The present work aims to study the characterization of $-25 \mu \mathrm{m}$ kaolin clay produced from processing of white sands to improve its physical properties. This was carried out by applying selective dispersion of kaolin and flocculation of colored minerals technique. Also, the removal of iron and titanium from $25 \mu \mathrm{m}$ kaolin clay product in acidic leaching conditions using organic acids was also attempted. In the leaching studies the effect of important parameters was investigated using Mathematical Statistical Factorial Design expert version 9.0 with box-Behnken design technique.

\subsection{Location and Geology}

Wadi-Qena is one of the largest wadies in the Eastern Desert of Egypt. Glass sands constitute most of the Lower Paleozoic Naqus Formation and are exposed in an area of approximately $450 \mathrm{~km} 2$ at the western margin of the northern part of Wadi-Qena. The quantity of sands available is enormous. 
Probable reserves were estimated to be 1 billion metric tons. It consists predominantly of white silica sands and Kaolinitic lenses [9]. Wadi-Qena covers an area of approximately $400 \mathrm{~km} 2$, represented by the western side of the valley of Qena, which separates the components of the basement rocks (Albraikambria) on the eastern side and the components of sedimentary rocks (Alvaneruszy) on the western side. This area includes white sand an actress created bell's and white sand covers by Alglala Created which consists of sandstone, shale and limestone containing the fossils. Thickness of this component (Alglala) changes from one area to another [10].

\section{Material and methods}

The used material is $-25 \mu \mathrm{m}$ kaolin product from attrition of Wadi-Qena Kaolinitic white sand. This Kaolinitic white sand was found as consolidated deposits without overburden (Open Pit Quarry). This deposit is situated in the North Eastern Desert, Egypt. It occupies an area of about four hundred square kilometers with coordinates, Latitudes $27^{\circ} 30^{\prime}, 28^{\circ} 10^{\prime} \mathrm{N}$ and longitudes $32^{\circ} 30^{\prime}, 32^{\circ} 40^{\prime} \mathrm{E}$. Beneficiation processes were conducted on the studied -25 kaolin product to improve their quality to meet the Standard specifications of industrial kaolin. These investigations or processes includes: 1Laboratory work deals with chemical analysis and mineralogical analysis of feed. 2- Beneficiation processes which include selective dispersion and flocculation. 3- Leaching process with sulfuric and oxalic acids and its Optimization using the Mathematical Statistical Factorial Design.

\subsection{Preparation of $\mathbf{- 2 5} \boldsymbol{\mu m}$ size fraction sample}

$50 \mathrm{~kg}$ of unconsolidated Kaolinitic white sand sample have been collected. It was kindly supplied by the Egyptian geological survey and mining authority. This sample was mixed thoroughly then a representative sample weighing about $1 \mathrm{~kg}$ was obtained by coning and quartering. Attrition scrubbing experiments were conducted on the representative sample using Denver flotation machine which use attrition kit unit. The attrition scrubbing conducted under the following conditions, Pulp density: 70 solid \% by wt., Impeller speed: $2400 \mathrm{rpm}$, Attrition time: $15 \mathrm{~min}$ and Attrition mode: once, twice and triple. To obtain $-25 \mu \mathrm{m}$ fraction, after the sample was wet sieved and deslimed on 0.6, 0.106 and $0.025 \mathrm{~mm}$ screens and dried as shown in table (1). The mineralogical analysis of the $-25 \mu \mathrm{m}$ fraction using XRD is shown in table (2) and Fig. (1).

Table (1): indicates Desliming of Wadi-Qena Kaolinitic white sand after attrition scrubbing.

\begin{tabular}{|c|c|c|}
\hline size fraction, $\mu \mathrm{m}$ & Wt., $\%$ & Cum. Ret., $\%$ \\
\hline+600 & 1.35 & 1.35 \\
\hline$-600+106$ & 84.25 & 85.5 \\
\hline$-106+25$ & 4.7 & 90.2 \\
\hline-25 & 9.8 & 100 \\
\hline Total & 100 & \\
\hline
\end{tabular}

Table (2): Mineralogical composition of $\mathbf{- 2 5} \boldsymbol{\mu \mathrm { m }}$ fraction

\begin{tabular}{|c|c|}
\hline Major constituent & Chemical composition \\
\hline Quartz, low & $\mathrm{SiO} 2$ \\
\hline Kaolinite & $\mathrm{Al} 2 \mathrm{Si} 2 \mathrm{O} 5(\mathrm{OH}) 4$ \\
\hline
\end{tabular}

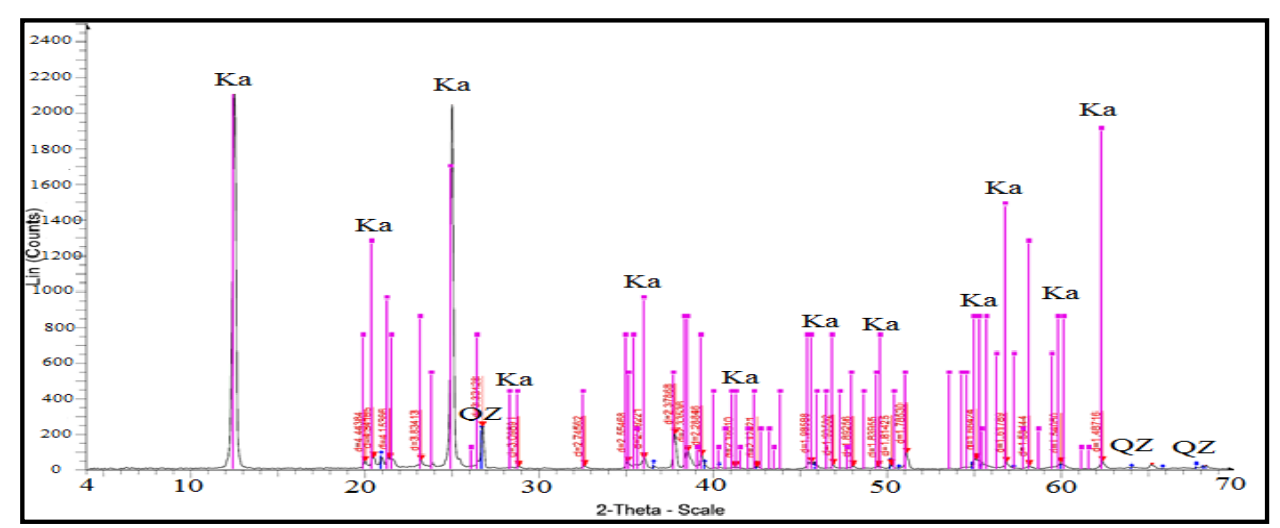

Figure1: pattern of $-25 \mu \mathrm{m}$ fraction 
The chemical analysis of the $-25 \mu \mathrm{m}$ sample from attrition and Desliming Kaolinitic white sand ore using (XRF) analysis revealed that the sample composed of various oxides such as $\mathrm{SiO} 2, \mathrm{Al} 2 \mathrm{O} 3$, $\mathrm{Fe} 2 \mathrm{O} 3, \mathrm{CaO}$, TiO2, Na2O, $\mathrm{K} 2 \mathrm{O}$ and P2O5. The major oxides are shown in table (3).

Table (3): Complete chemical analysis of $-25 \mu \mathrm{m}$ fraction.

\begin{tabular}{|c|c|}
\hline Constituent & Wt.\% \\
\hline $\mathrm{SiO} 2$ & 47.724 \\
\hline $\mathrm{Al} 2 \mathrm{O} 3$ & 36.054 \\
\hline $\mathrm{Fe} 2 \mathrm{O} 3$ & 0.623 \\
\hline $\mathrm{TiO} 2$ & 1.669 \\
\hline $\mathrm{CaO}$ & 0.319 \\
\hline $\mathrm{MgO}$ & 0.158 \\
\hline $\mathrm{Na} 2 \mathrm{O}$ & 0.082 \\
\hline $\mathrm{K} 2 \mathrm{O}$ & 0.039 \\
\hline $\mathrm{P} 2 \mathrm{O} 5$ & 0.209 \\
\hline $\mathrm{Cl}$ & 0.038 \\
\hline $\mathrm{SO} 3$ & 0.086 \\
\hline ZnO & 0.012 \\
\hline ZrO2 & 0.053 \\
\hline L.O.I & 12.8 \\
\hline Total & $100 \%$ \\
\hline
\end{tabular}

\subsection{Beneficiation studies}

To obtain the specifications of applications of kaolin, upgrading techniques including selective dispersion of kaolin / flocculation of colored minerals of $-25 \mu \mathrm{m}$ fraction and leaching of colored mineral oxide of $-25 \mu \mathrm{m}$ fraction are applied. To optimize the leaching process, Mathematical Statistical Factorial Design version 9.0 was applied.

\subsubsection{Selective dispersion of kaolin and flocculation of colored minerals.}

Aqueous suspensions of kaolin with $40 \%$ solids content were prepared. Sodium silicate $(2 \mathrm{~kg} / \mathrm{ton})$ followed by Sodium hexametaphosphate $(4 \mathrm{~kg} / \mathrm{ton})$ were added to kaolin clay suspension as dispersants. Sodium hydroxide was added to adjust $\mathrm{pH}$. The suspension was plunged at $1000 \mathrm{rpm}$ for 45 min period. In a second step, kaolin clay suspension was diluted to $12 \%$. The suspension was conditioned at $1000 \mathrm{rpm}$ for $15 \mathrm{~min}$, with different dosage $(5,10,15$ and $20 \mathrm{~g} / \mathrm{t})$ of polyacrylamide as surfactant or flocculant for iron oxides. To study the influence of $\mathrm{pH}$ on selective flocculation, the $\mathrm{pH}$ of suspension was adjusted to $7,8,9,10$ and 11 . These samples were poured into graduated $(250 \mathrm{~mL})$ cylinder, stirred for $2 \mathrm{~min}$ and submitted to sedimentation for $30 \mathrm{~min}$. Thereafter the overflow and underflow was separated.

\subsubsection{Optimization of the leaching process of $-25 \mu \mathrm{m}$ fraction using Mathematical Statistical Factorial Design}

All leaching tests were conducted in a $250 \mathrm{ml}$ conical flask placed over a hot plate magnetic stirrer. $20 \mathrm{~g}$ of sample $(-25 \mu \mathrm{m})$ was added in $100 \mathrm{ml}$ of an acid solutions of different concentrations for different times and constant temperature of $90^{\circ} \mathrm{C}$ under continuous stirring of $200 \mathrm{rpm}$. The content was then filtered, repeatedly washed with distilled water to remove any unspent acid, and dried at 120 ${ }^{\circ} \mathrm{C}$ for $2 \mathrm{~h}$. The filter cake was examined by ICP-MS (Inductive coupled plasma mass spectrophotometry) in order to measure its content of Fe and Ti. While acid concentration (sulfuric acid concentration), reducing agent concentration (oxalic concentration) and leaching time were variable parameters, stirring rate and temperature were kept constant during leaching process. The main purpose of the design of the experiment is to find out the common relationship between the multiple process variables in order to determine the optimum operating conditions for the system. It is essential that the design methodology should be economical as well as it should also reduce 
experimental time to save both material and personnel cost $[11,12]$. This combined process (leaching process) was modeled and optimized using a Box-Behnken design (BBD) with response surface methodology (RSM). The effects of sulfuric acid concentration, oxalic acid concentration and time were investigated. RSM is an empirical optimization technique for evaluating the relationship between experimental outputs (or responses) and factors called X1, X2, X3, etc. This method (RSM) is usually used in combination with factorial design methods such as Box-Behnken designs and centralcomposite designs. Adopting Box-Behnken designs (BBD) can sharply reduce the number of experimental sets without decreasing the accuracy of the optimization compared with traditional factorial design methods. The minimum and maximum ranges for the three factors are illustrated in terms of coded and uncoded symbols in table (4). In order to evaluate the significance of regression model and effect of the factors and their interactions analysis of variance (ANOVA) was performed. ANOVA is a statistical technique that subdivides the total variation in asset of data into component parts associated with specific sources of variation for the purpose of testing hypotheses on the parameters of the model $[13,14]$. To evaluate the interaction effects of sulfuric acid concentration, Oxalic acid concentration, and time in the formulations; 3-factor, 3-level Box Behnken design was used. A total of 15 experimental runs were generated by design expert software, for which nonlinear computer generated quadratic model is shown below $[15,16]$.

$$
Y=\beta_{0}+\beta_{1} X_{1}+\beta_{2} X_{2}+\beta_{3} X_{3}+\beta_{12} X_{1} X_{2}+\beta_{13} X_{1} X_{3}+\beta_{23} X_{2} X_{3}+\beta_{11} X_{12}+\beta_{22} X_{22}+\beta_{33} X_{32}
$$

Table (4): Minimum and maximum levels of the three studied factors in terms of coded and uncoded symbols.

\begin{tabular}{|c|c|c|c|c|c|}
\hline \multirow{2}{*}{ Variables } & \multicolumn{2}{|c|}{ Symbols } & \multicolumn{3}{c|}{ Levels } \\
\cline { 2 - 6 } & Coded & uncoded & -1 & 0 & 1 \\
\hline Sulfuric concentration (molar) & $\mathrm{x}_{1}$ & $\mathrm{X}_{1}$ & 1 & 3 & 5 \\
\hline Oxalic concentration $(\mathrm{g} / \mathrm{l})$ & $\mathrm{x}_{2}$ & $\mathrm{X}_{2}$ & 10 & 30 & 50 \\
\hline Time $(\mathrm{hr})$ & $\mathrm{x}_{3}$ & $\mathrm{X}_{3}$ & 1 & 2 & 3 \\
\hline
\end{tabular}

The number of experiments $(\mathrm{N})$ required for development of BBD is defined as [17].

$\mathrm{N}=2 \mathrm{k}(\mathrm{k}-1)+\mathrm{C}_{0}$

The relationship between the coded variables and uncoded variables is described by the following equations:

$$
\begin{aligned}
& \mathrm{x}_{1}=\left(\mathrm{X}_{1}-3\right) / 2 \\
& \mathrm{x}_{2}=(\mathrm{X} 2-30) / 20 \\
& \mathrm{x}_{3}=(\mathrm{X} 3-2) / 1
\end{aligned}
$$

Where $\mathrm{X}_{1}, \mathrm{X}_{2}$ and $\mathrm{X}_{3}$ are the uncoded variables and $\mathrm{x}_{1}, \mathrm{x}_{2}$, and $\mathrm{x}_{3}$ are the coded variables. Obviously, all three uncoded factors have their own units. By introducing coded variables, we make the factors dimensionless [18]. Box-Behnken response surface experimental design does not only help in determining the accurate values of experimental parameters but also provides the possibility to evaluate the interaction between variables with a reduced number of experiments. Table (5) shows Box-Behnken design for development and optimization of the leaching process of $(-25 \mu \mathrm{m})$ kaolin fraction using the Mathematical Statistical Factorial Design by Design version.9 Expert Software [19]. 
PROCESSING OF WADI QENA KAOLINITIC WHITE SANDS BY SELECTIVE DISPERSION AND LEACHING FOR INDUSTRIAL USES

Table (5): Box-Behnken design for development of the leaching process for $(-25 \mu \mathrm{m})$ fraction.

\begin{tabular}{|c|c|c|c|}
\hline \multirow{2}{*}{ No } & \multicolumn{3}{|c|}{ Dependent variables } \\
\cline { 2 - 4 } & $\begin{array}{c}\text { Sulfuric } \\
\text { concentration } \\
\text { (molar) }\end{array}$ & $\begin{array}{c}\text { Oxalic } \\
\text { concentration } \\
(\mathrm{g} / \mathrm{l})\end{array}$ & $\begin{array}{c}\text { Time } \\
(\mathrm{min})\end{array}$ \\
\hline 1 & 5 & 50 & 2 \\
\hline 2 & 3 & 30 & 2 \\
\hline 3 & 1 & 30 & 1 \\
\hline 4 & 3 & 50 & 1 \\
\hline 5 & 5 & 30 & 3 \\
\hline 6 & 1 & 30 & 3 \\
\hline 7 & 5 & 10 & 2 \\
\hline 8 & 3 & 10 & 1 \\
\hline 9 & 1 & 10 & 2 \\
\hline 10 & 3 & 30 & 2 \\
\hline 11 & 5 & 30 & 1 \\
\hline 12 & 3 & 50 & 3 \\
\hline 13 & 3 & 30 & 2 \\
\hline 14 & 3 & 10 & 3 \\
\hline 15 & 1 & 50 & 2 \\
\hline
\end{tabular}

\section{RESULTS AND DISCUSSION}

\subsection{Selective dispersion of kaolin.}

\subsubsection{Effect of polymer dosage on the physical properties of $\mathbf{- 2 5} \boldsymbol{\mu m}$ Kaolin.}

The effect of flocculant concentration on the flocculation of colored minerals from kaolin was investigated by using different polymer dosages $5,10,15$, and $20 \mathrm{~g}$ ton. The experiments were carried out at $40 \%$. Pulp density during conditioning; $12 \%$ Pulp density during separation, $2 \mathrm{~kg} / \mathrm{t}$. Sodium silicate, followed by $4 \mathrm{~kg} / \mathrm{t}$ Sodium hexametaphosphate as a dispersant, $\mathrm{pH} .9 .5$ during conditioning and $\mathrm{pH} .9$ during separation. It can be seen that the best performance in terms of physical properties of the overflow kaolin product was achieved at polymer dosage of $15 \mathrm{~g} /$ ton as shown in Figures (2) and (3). The brightness of dispersed kaolin increased from 76.45 to 81.32 , Iso-brightness increased from 84.15 to 86.85 , whiteness increased from 91.73 to 93.18 , redness decreased from 0.22 to 0.17 and yellowness decreased from 5.84 to 3.96 .

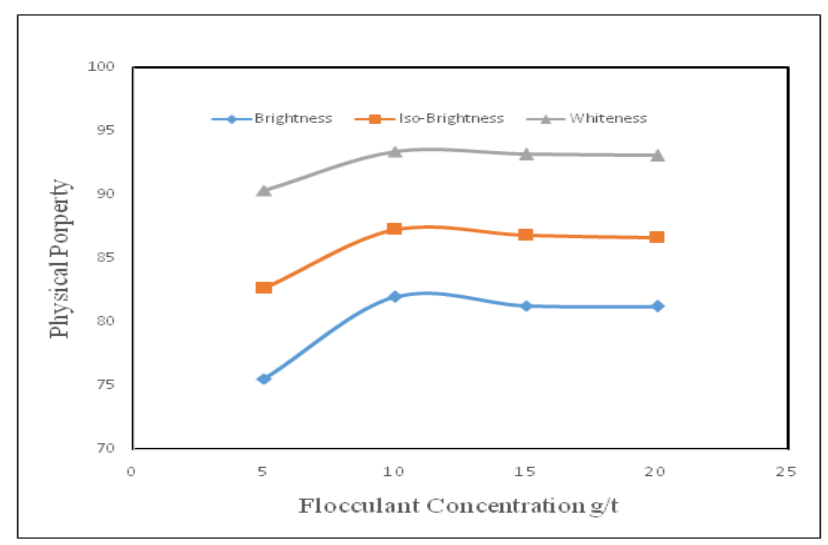

Figure 2. Brightness, Iso-Brightness and whiteness of the kaolin product, after sedimentation step at different flocculant concentrations. 


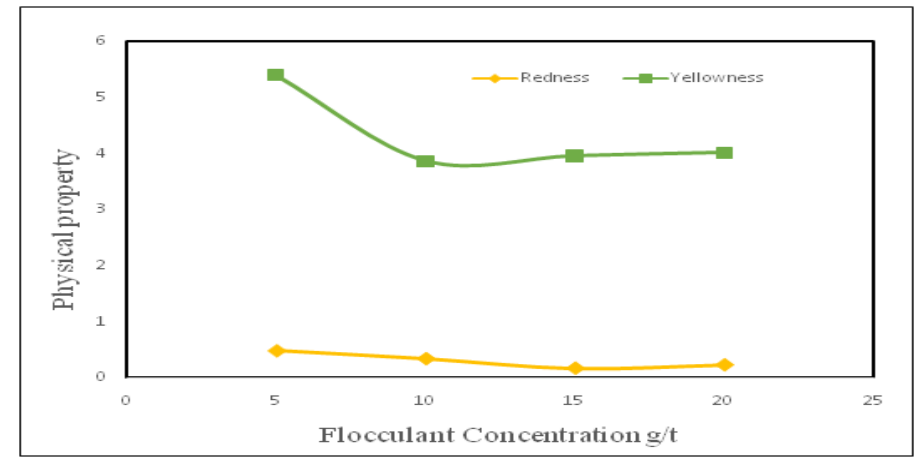

Figure 3. Redness and Yellowness of the kaolin product, after sedimentation step at different flocculant concentrations.

\subsubsection{Effect of $\mathbf{p H}$ during separation on the physical properties of Kaolin $\mathbf{- 2 5} \boldsymbol{\mu m}$ product} during dispersion of Kaolin and flocculating of colored mineral.

The effect of $\mathrm{pH}$ during separation on flocculation of colored minerals was investigated by using different $\mathrm{pH}$ values of $7,8,9,10$ and 11 . The typical operating conditions were conducted as follows $15 \mathrm{~g} / \mathrm{t}$ flocculant concentration during separation. The experiments were carried out at $40 \%$. Pulp density during conditioning; $12 \%$ Pulp density during separation, $2 \mathrm{~kg} / \mathrm{t}$. Sodium silicate, $4 \mathrm{~kg} / \mathrm{t}$ Sodium hexametaphosphate and pH. 9.5 during conditioning. The results are shown in figures (4) and (5). It can be seen that the best performance in terms of the physical properties of the overflow kaolin product was achieved at $\mathrm{pH} 9$ for flocculant applied in the present study. The brightness increased from 76.45 to 81.32 , Iso-brightness increased from 84.15 to 86.85 , whiteness increased from 91.73 to 93.18, redness decreased from 0.22 to 0.17 and yellowness decreased from 5.84 to 3.96. The selective adsorption of flocculants is better at $\mathrm{pH} 9$, where negative charges present on the kaolin surfaces help in adsorbing the titanoferrous mineral surfaces by polyacrylamide polymers [20].

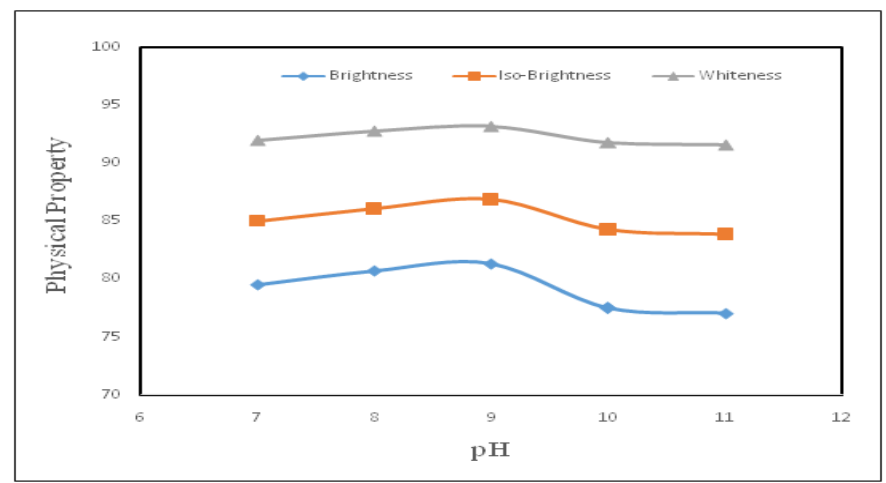

Figure 4. Brightness, Iso-Brightness and whiteness of overflow product (kaolin), after sedimentation step at different $\mathrm{pH}$ values.

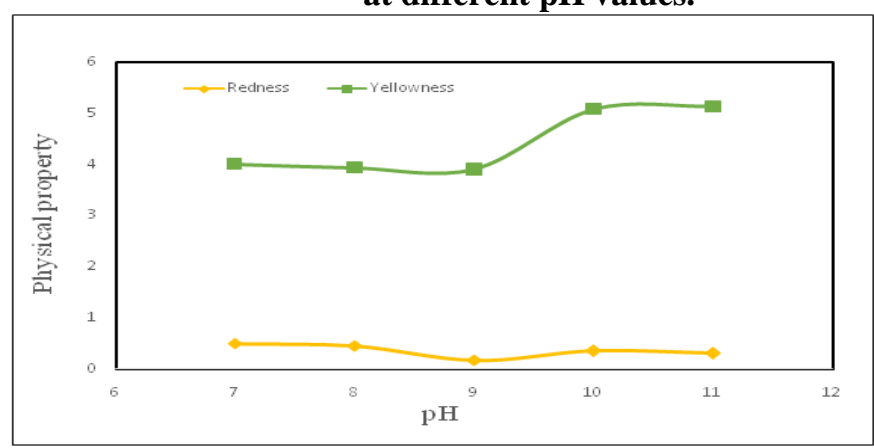

Fig -5: Shows Redness and Yellowness of overflow product (kaolin), after sedimentation step at different pH values. 


\subsection{Optimization of leaching process of $-25 \mu \mathrm{m}$ kaolin sample with Box-Behnken design method (BBD).}

\subsubsection{Regression model representation}

A 3 factor 3 level Box-Behnken design (BBD) for (Response Surface Method) RSM was used to study the correlation between the combined effect of individual parameters and two responses over three levels. The experimental design matrix and the responses based on experimental runs proposed by BBD are given in Table (6). No transformation was chosen while analyzing both the responses. Among the linear, two-factor interaction (2FI) and quadratic polynomials, the quadratic model was suggested to be the most suitable for this process by the Design-Expert ${ }^{\circledR}$ Software, Version 9.0 (StatEase, Minneapolis, USA). It showed a lower standard deviation along with higher $\mathrm{R}^{2}$ values. Final equations in terms of coded factors for responses $\mathrm{Y} 1\left(\mathrm{Fe}_{2} \mathrm{O}_{3} \%\right)$ and $\mathrm{Y}_{2}\left(\mathrm{TiO}_{2} \%\right)$ in kaolin residue are obtained as follows,

Table (6): Box-Behnken design for development and optimization of the flotation process for (-25 $\boldsymbol{\mu m})$.

\begin{tabular}{|c|c|c|c|c|c|c|c|}
\hline \multirow{2}{*}{ No } & \multicolumn{2}{|c|}{\begin{tabular}{c} 
Dependent variables \\
concentration \\
\cline { 5 - 9 }
\end{tabular}} & $\begin{array}{c}\text { Oxalic } \\
\text { (molar) }\end{array}$ & \multirow{2}{*}{$\begin{array}{c}\text { Time } \\
(\mathrm{g} / \mathrm{l})\end{array}$} & \multicolumn{4}{|c|}{$\mathrm{Fe}_{2} \mathrm{O}_{3} \%$} & \multicolumn{2}{|c|}{$\mathrm{TiO}_{2} \%$} \\
\cline { 5 - 9 } & $(\mathrm{min})$ & actual & predicted & actual & predicted \\
\hline 1 & 5 & 50 & 2 & 0.218 & 0.216375 & 0.307 & 0.312 \\
\hline 2 & 3 & 30 & 2 & 0.29 & 0.28 & 0.284 & 0.270667 \\
\hline 3 & 1 & 30 & 1 & 0.245 & 0.242 & 0.44 & 0.456 \\
\hline 4 & 3 & 50 & 1 & 0.232 & 0.230375 & 0.415 & 0.391 \\
\hline 5 & 5 & 30 & 3 & 0.215 & 0.218 & 0.324 & 0.308 \\
\hline 6 & 1 & 30 & 3 & 0.232 & 0.22875 & 0.4 & 0.381 \\
\hline 7 & 5 & 10 & 2 & 0.209 & 0.204375 & 0.184 & 0.176 \\
\hline 8 & 3 & 10 & 1 & 0.222 & 0.223375 & 0.374 & 0.363 \\
\hline 9 & 1 & 10 & 2 & 0.22 & 0.221625 & 0.427 & 0.422 \\
\hline 10 & 3 & 30 & 2 & 0.28 & 0.28 & 0.264 & 0.270667 \\
\hline 11 & 5 & 30 & 1 & 0.222 & 0.22525 & 0.329 & 0.348 \\
\hline 12 & 3 & 50 & 3 & 0.223 & 0.221625 & 0.275 & 0.286 \\
\hline 13 & 3 & 30 & 2 & 0.27 & 0.28 & 0.264 & 0.270667 \\
\hline 14 & 3 & 10 & 3 & 0.21 & 0.211625 & 0.329 & 0.353 \\
\hline 15 & 1 & 50 & 2 & 0.222 & 0.226625 & 0.239 & 0.247 \\
\hline
\end{tabular}

$\mathrm{Y} 1=+0.28-6.875 * 10^{-3} \mathrm{X}_{1}+4.250 * 10^{-3} \mathrm{X}_{2}-5.125 * 10^{-3} \mathrm{X}_{3}+1.750 * 10^{-3} \mathrm{X}_{1} \mathrm{X}_{2}+1.500 * 10^{-3} \mathrm{X}_{1} \mathrm{X}_{3}+$

$\mathrm{Y} 2=+0.27-0.045 \mathrm{X}_{1}-9.750 * 10^{-3} \mathrm{X}_{2}-0.029 \mathrm{X}_{3}+0.078 \mathrm{X}_{1} \mathrm{X}_{2}+8.750 * 10^{3} \mathrm{X}_{1} \mathrm{X}_{3}-0.024 \mathrm{X}_{2} \mathrm{X}_{3}+$

$0.022 \mathrm{X}_{12}-3.208 * 10^{-3} \mathrm{X}_{22}+0.081 \mathrm{X}_{32}$

The predicted values of the responses were determined by the aforementioned equations. The positive sign of the coefficients in regression equation indicated a synergistic effect, while the negative sign represented an antagonistic effect on the response [21]. From Eq. (9), it was evident that the constant 0.28 was independent of any factor or interaction of the factors, the linear terms $\mathrm{X}_{1}, \mathrm{X}_{3}$ and secondorder $\mathrm{X}_{12}, \mathrm{X}_{22}, \mathrm{X}_{32}$ had a negative effect on the $\left(\mathrm{Fe}_{2} \mathrm{O}_{3} \%\right)$ response. Hence the response increased as these terms decreased, whereas the terms $X_{2}, X_{1} X_{2}, X_{1} X_{3}$ and $X_{2} X_{3}$ had a positive influence which denoted that there would be a decrease in $\mathrm{Fe}_{2} \mathrm{O}_{3} \%$ with the decrease in the magnitude of these parameters. Similarly, from Eq. (10) it was evident that the constant 0.27 was independent of the 
studied parameters. The linear terms $\mathrm{X}_{1}, \mathrm{X}_{2}$ and $\mathrm{X}_{3}$, interaction terms $\mathrm{X}_{2} \mathrm{X}_{3}$ and second-order term $\mathrm{X}_{22}$ had a (-ve) effect with the $\mathrm{TiO}_{2} \%$ response whereas the interaction terms $\mathrm{X}_{1} \mathrm{X}_{2}, \mathrm{X}_{1} \mathrm{X}_{3}$, quadratic terms $\mathrm{X}_{12}, \mathrm{X}_{32}$ had a (+ ve) effect on the response $\left(\mathrm{TiO}_{2} \%\right)$.

\subsubsection{Statistical analysis}

A statistical analysis of variance (ANOVA) based on BBD was performed with designExpert ${ }^{\circ}$ Software, Version 9.0 (Stat-Ease, Minneapolis, USA) proposed to determine the fitness and significance of the proposed model. ANOVA is an analytical technique that is used to identify the importance of the model and its parameters, using Fisher's $F$-test. It also determines the effects of the individual variables and interactions between them on the responses. The model and model terms are considered to be significant only when the values (Prob > F) are less than 0.0500 and terms with Fisher's statistical test F-test (F model, mean square regression/mean square residual) value have greater importance to produce an effect on the response [22,23]. The ANOVA assessed the significance of the fitting of the quadratic model for both responses ( $\mathrm{Y} 1$ and $\mathrm{Y} 2$ ). The results for response surface of $\mathrm{Y} 1\left(\mathrm{Fe}_{2} \mathrm{O}_{3} \%\right)$ is shown in Table (7).

Table (7): ANOVA for response surface quadratic model of $\mathrm{Y} 1\left(\mathrm{Fe}_{2} \mathrm{O}_{3} \%\right)$.

\begin{tabular}{|c|c|c|c|c|c|c|}
\hline Source & $\begin{array}{l}\text { Sum of } \\
\text { Squares }\end{array}$ & df & $\begin{array}{l}\text { Mean } \\
\text { Square }\end{array}$ & $\begin{array}{c}\mathrm{F} \\
\text { Value }\end{array}$ & $\begin{array}{c}\text { p-value } \\
\text { Prob }>\text { F }\end{array}$ & \\
\hline Model & $8.948 * 10-3$ & 9 & $9.942 * 10-4$ & 16.78 & 0.0032 & significant \\
\hline X1-sulfuric acid concentration & $3.781 * 10-4$ & 1 & $3.781 * 10-4$ & 6.38 & 0.0528 & \\
\hline X2-oxalic acid concentration & $1.445 * 10-4$ & 1 & $1.445 * 10-4$ & 2.44 & 0.1791 & \\
\hline X3-time & $2.101 * 10-4$ & 1 & $2.101 * 10-4$ & 3.55 & 0.1184 & \\
\hline $\mathrm{X} 1 \mathrm{X} 2$ & $1.225 * 10-5$ & 1 & $1.225 * 10-5$ & 0.21 & 0.6684 & \\
\hline $\mathrm{X} 1 \mathrm{X} 3$ & $9.000 * 10-6$ & 1 & $9.000 * 10-6$ & 0.15 & 0.7128 & \\
\hline $\mathrm{X} 2 \mathrm{X} 3$ & $2.250 * 10-6$ & 1 & $2.250 * 10-6$ & 0.038 & 0.8532 & \\
\hline $\mathrm{X} 12$ & $2.895 * 10-3$ & 1 & $2.895 * 10-3$ & 48.86 & 0.0009 & \\
\hline $\mathrm{X} 22$ & $4.459 * 10-3$ & 1 & $4.459 * 10-3$ & 75.25 & 0.0003 & \\
\hline X32 & $2.039 * 10-3$ & 1 & $2.039 * 10-3$ & 34.41 & 0.0020 & \\
\hline Residual & $2.962 * 10-4$ & 5 & $5.925 * 10-5$ & & & \\
\hline Lack of Fit & $9.625 * 10-5$ & 3 & $3.208 * 10-5$ & 0.32 & 0.8148 & not significant \\
\hline Pure Error & $2.000 * 10-4$ & 2 & $1.000 * 10-4$ & & & \\
\hline Cor Total & $9.244 * 10-3$ & 14 & & & & \\
\hline
\end{tabular}

$\mathrm{R} 2=0.9680$, Adj.R2 $=0.9103$, Adequate Precision $=12.033, \mathrm{CV}=3.29 \%$, Standard Deviation $=$ $7.697 * 10-3$.

A model F-value of 16.78 with (Prob > F) equal 0.0032 for response $\mathrm{Y}_{1}\left(\mathrm{Fe}_{2} \mathrm{O}_{3} \%\right)$ verified the sufficiency of the model as shown from Table (7). From the ANOVA table, the model terms $X_{1}, X_{12}$, $\mathrm{X}_{22}$ and $\mathrm{X}_{32}$ were observed to be statistically significant. However, the model terms $\mathrm{X}_{2}, \mathrm{X}_{3}, \mathrm{X}_{1} \mathrm{X}_{2}$, $\mathrm{X} 1 \mathrm{X} 3$ and $\mathrm{X} 2 \mathrm{X} 3$ were statistically insignificant. The main factor sulfuric acid concentration had a significant effect on the $\mathrm{Fe}_{2} \mathrm{O}_{3} \%$. The coefficient of determination (R2) of the model for response Y1 was noted as 0.9680 which suggested that the fitted polynomial equations had a good degree of fitness of the model and only about 0.032 of the total variation cannot be explained by the fitted model. The "pred R-squared" of 0.7847 was in reasonable agreement with the "adj R-squared" of 0.9103 because the difference between these values is within 0.2 which confirmed good predictability of the model. Moreover. For response $Y_{1}$ the standard deviation of the model was $7.697 * 10-3$. This confirm the goodness of the model since the smaller the value of standard deviation the better is the model because the predicted value obtained will be found closer to the actual value. "Adequate precision" is a measure of the signal to noise ratio and a value greater than or equal to 4 is always desirable. In the present analysis, a value of 12.033 indicated sufficient model discrimination. On the other hand, a 
relatively lower value of the coefficient of variation $(\mathrm{CV}=3.29 \%)$ indicated good precision and reliability of the model.

Results of ANOVA (response of $\mathrm{Y} 2:(\mathrm{TiO} 2 \%)$ ) is shown in Table (8). It indicates that the model was highly significant as the Fisher F-test $(\mathrm{F}$ model, S2reg/S2err $=13.73)$ with a very low probability value $[(\mathrm{P}>\mathrm{F})=0.005]$. The main effect $\mathrm{X}_{1}, \mathrm{X}_{3}$; the two-level interactions of sulfuric acid concentration and oxalic acid concentration $\left(\mathrm{X}_{1} \mathrm{X}_{2}\right)$; the second-order effect of leaching time $\left(\mathrm{X}_{32}\right)$ were the significant model terms. Other model terms were statistically insignificant. It was found that the coefficient of determination $\left(\mathrm{R}^{2}\right)$ was 0.9611 , which was very high and indicates a good correlation. As well, the adjusted $\mathrm{R}^{2}$ value (0.8911) was also high to advocate the significance of the model, which ensured a satisfactory adjustment of the experimental data to the polynomial model. The difference between adj $\mathrm{R}$-squared and pre R-squared value was more than 0.2 which indicates a blocking effect for which model reduction was necessary. "Adequate precision" is a measure of the signal to noise ratio and a value greater than or equal to 4 is always desirable. The ratio of 13.8333 for response Y2 indicates an adequate signal and so the model could be used to navigate the design space. Simultaneously, a low value of the coefficient of variation $(\mathrm{CV}=7.66 \%)$ denoted good accuracy and reliability of the model $[24,25]$.

Table (8): ANOVA for response surface quadratic model of Y2 (TiO2\%).

\begin{tabular}{|c|c|c|c|c|c|c|}
\hline Source & $\begin{array}{l}\text { Sum of } \\
\text { Squares }\end{array}$ & df & $\begin{array}{l}\text { Mean } \\
\text { Square }\end{array}$ & $\begin{array}{c}\mathbf{F} \\
\text { Value }\end{array}$ & $\begin{array}{c}\text { p-value } \\
\text { Prob > F }\end{array}$ & \\
\hline Model & 0.076 & 9 & $8.435 * 10^{-3}$ & 13.73 & 0.0050 & significant \\
\hline $\mathrm{X}_{1}$-sulfuric acid concentration & 0.016 & 1 & 0.016 & 26.66 & 0.0036 & \\
\hline $\mathrm{X}_{2}$-oxalic acid concentration & $7.605^{*} 10^{-4}$ & 1 & $7.605^{*} 10^{-4}$ & 1.24 & 0.3166 & \\
\hline $\mathrm{X}_{3}$-time & $6.612 * 10^{-3}$ & 1 & $6.612 * 10^{-3}$ & 10.76 & 0.0219 & \\
\hline $\mathrm{X}_{1} \mathrm{X}_{2}$ & 0.024 & 1 & 0.024 & 39.35 & 0.0015 & \\
\hline $\mathrm{X}_{1} \mathrm{X}_{3}$ & $3.063 * 10^{-3}$ & 1 & $3.063 * 10^{-4}$ & 0.50 & 0.5118 & \\
\hline $\mathrm{X}_{2} \mathrm{X}_{3}$ & $2.256^{*} 10^{-3}$ & 1 & $2.256^{*} 10^{-3}$ & 3.67 & 0.1135 & \\
\hline $\mathrm{X}_{1}^{2}$ & $1.753 * 10^{-3}$ & 1 & $1.753 * 10^{-3}$ & 2.85 & 0.1520 & \\
\hline $\mathrm{X}_{2}{ }^{2}$ & $3.801 * 10^{-5}$ & 1 & $3.801 * 10^{-5}$ & 0.062 & 0.8135 & \\
\hline $\mathrm{X}_{3}^{2}$ & 0.024 & 1 & 0.024 & 39.22 & 0.0015 & \\
\hline Residual & $3.073 * 10^{-3}$ & 5 & $6.145^{*} 10^{-4}$ & & & \\
\hline Lack of Fit & $2.806^{*} 10^{-3}$ & 3 & $9.353 * 10^{-4}$ & 7.02 & 0.1273 & not significant \\
\hline Pure Error & $2.667 * 10^{-4}$ & 2 & $1.333 * 10^{-4}$ & & & \\
\hline Cor Total & 0.079 & 14 & & & & \\
\hline
\end{tabular}

\subsubsection{Model accuracy check}

A normal plot of residuals between the normal probability $(\%)$ and the internally studentized residuals is presented obtained. In this way, the residuals can be checked to determine how well the model satisfies the assumptions of ANOVA. The studentized residuals can be used to measure the standard deviations separating the experimental and predicted values. Figures (6) and (7) show the relationship between the normal probability (\%) and the internally studentized residuals. The straight line means that no response transformation is required and that there was no apparent problem with normality [26]. 


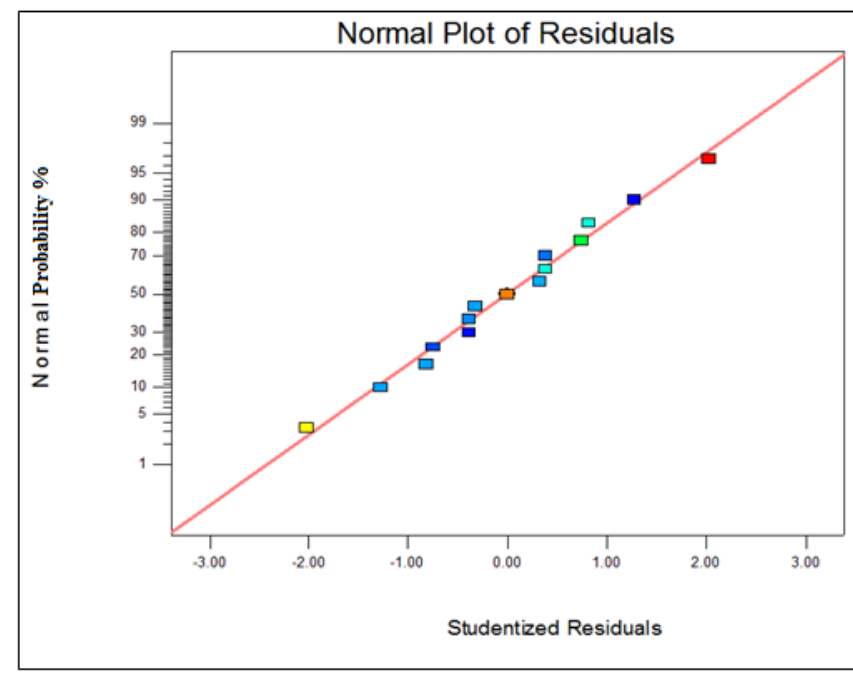

Figure 6. Normal plot of studentized residuals for $\mathrm{Fe}_{2} \mathrm{O}_{3}(\%)$.

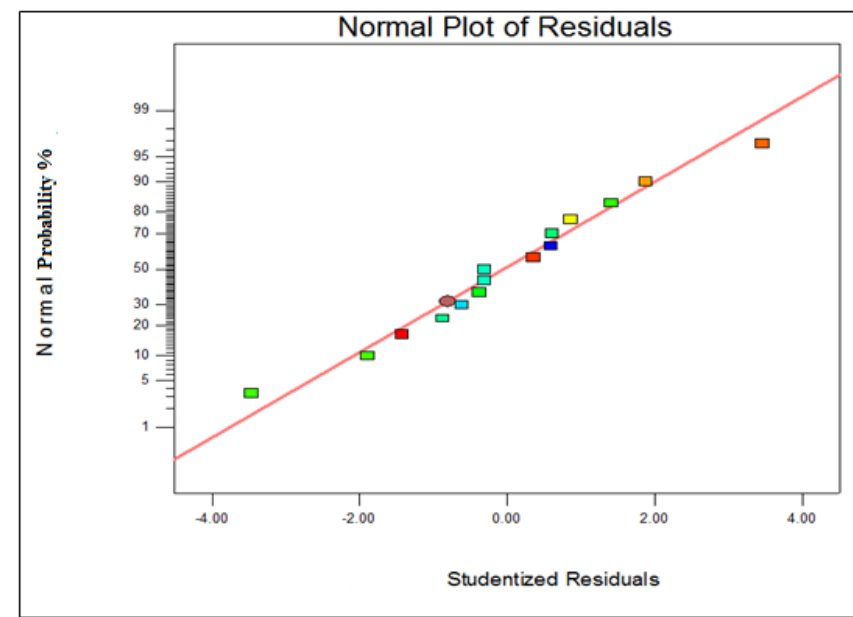

Figure 7. Normal plot of studentized residuals for $\mathrm{TiO}_{2}(\%)$.

To obtain an adequate model, an accuracy check is necessary. The model accuracy was checked by comparing the predicted and actual experimental values. The predicted versus actual plots for responses Y1 andY2 are shown in Figures (8) and (9). The experimentally obtained data for each run is the actual value whereas the predicted value is evaluated from the model using the proposed prediction equation. From both plots, it was observed that the most of the data points are well distributed near to the straight line, which suggested an excellent relationship between the experimental and predicted values of the responses.

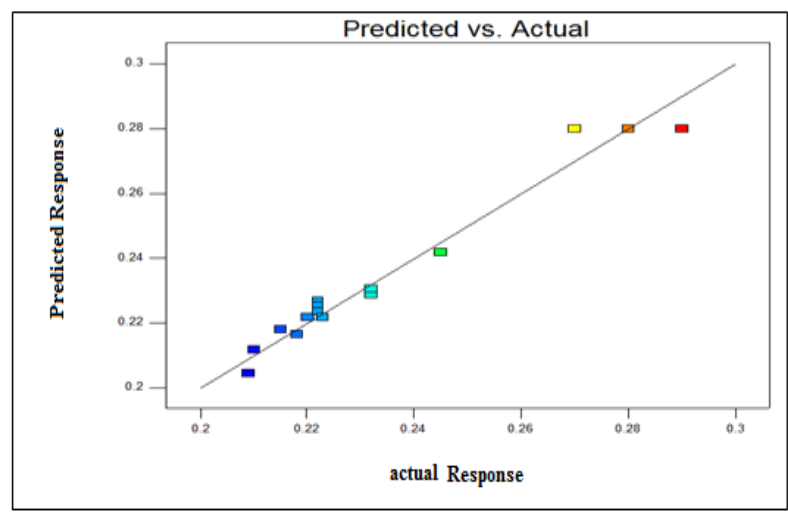

Figure 8. Plot of actual response versus predicted response for $\mathrm{Fe} 2 \mathrm{O3}(\%)$. 


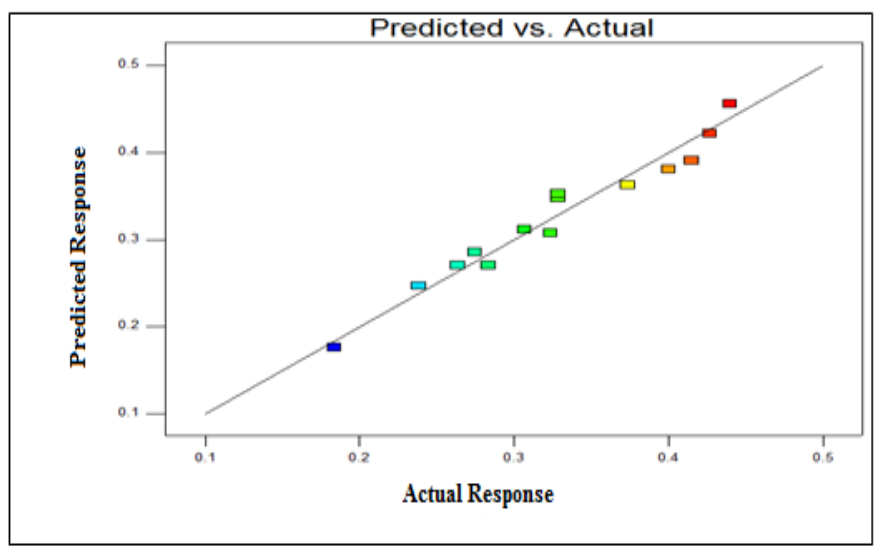

Figure 9. Plot of actual response versus predicted response for $\mathrm{TiO} 2(\%)$.

\subsubsection{Interaction effect of process variables on responses}

The 3-D response graphs for the $\mathrm{Fe}_{2} \mathrm{O}_{3}$ are depicted in some figures to indicate relation between parameters. The 3-D plots were generated using Design-Expert® Software, Version 9.0 (Stat-Ease, Minneapolis, USA) by varying two parameters within the range and keeping the other variable at constant level. Figure (10) demonstrates the no significant mutual interaction between sulfuric acid concentration $\left(\mathrm{X}_{1}\right)$ and oxalic acid concentration $\left(\mathrm{X}_{2}\right)$ for $\mathrm{Fe}_{2} \mathrm{O}_{3} \%$ response at constant time (3hours). It was noted that as the sulfuric acid concentration increases from 1-5 molar and oxalic acid concentration decreases to $10 \mathrm{~g} / \mathrm{l}$, the $\mathrm{Fe}_{2} \mathrm{O}_{3}$ loss was high i.e. $0.623-0.177 \%$. Results from 3-D surface plot when keeping the sulfuric acid concentration and oxalic concentration in the mentioned range at constant time indicates that the best results are obtained at 5 molar sulfuric acid concentrations, $10 \mathrm{~g} / \mathrm{l}$ oxalic acid concentration and at a time 3 hour. These results indicated that the sample is easily amenable to sulfuric acid leaching and the design shows significant sulfuric acid concentration and in significant interaction between variables. This may be attributed to the consumption of a great part of sulfuric acid in side reactions.

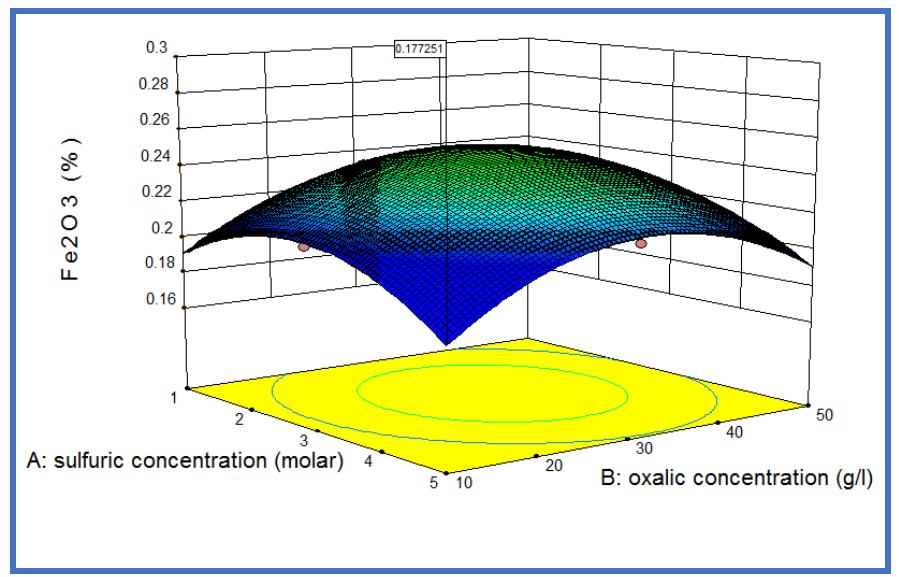

Figure10.The combined effect of interaction between sulfuric acid concentration (X1) and oxalic acid concentration (X2) for $\mathrm{Fe} 2 \mathrm{O3}$ content (\%) at constant time (3) hrs.

Figure (11) demonstrates the significant mutual interaction between sulfuric acid concentration $\left(\mathrm{X}_{1}\right)$ and oxalic acid concentration $\left(\mathrm{X}_{2}\right)$ for $\mathrm{TiO}_{2} \%$ response at constant time (2hours). It is noted that as the sulfuric acid concentration increases from 1-5 molar and oxalic acid concentration decreases to 10 $\mathrm{g} / \mathrm{l}$, the $\mathrm{Fe}_{2} \mathrm{O}_{3}$ loss was high i.e. $1.669-0.178 \%$. These results indicated that the sample is easily amenable to sulfuric acid leaching and the design shows significant sulfuric acid concentration, time and in significant oxalic acid concentration. The design indicates significant interaction between sulfuric acid and oxalic acid, sulfuric acid and time and no significant relationship between oxalic acid and time. This may be attributed to the consumption of a great part of sulfuric acid in side reactions with increase time and the stability of oxalic acid at a constant value. 


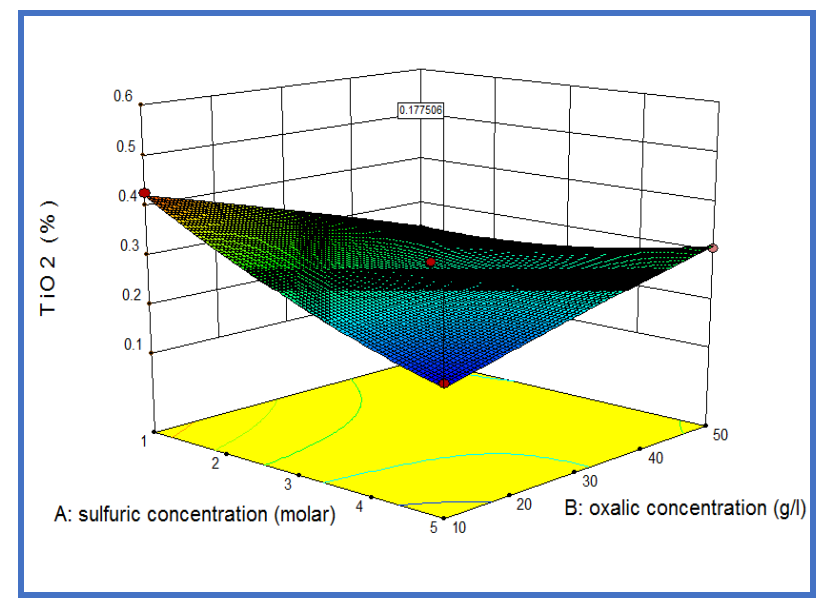

Figure (11): The combined effect of interaction between sulfuric acid concentration (X1) and oxalic acid concentration (X2) for $\mathrm{TiO} 2$ content (\%) at constant time (2) hrs.

\subsubsection{Process optimization}

In processing of $(-25 \mu \mathrm{m})$ kaolin by leaching with sulfuric acid and oxalic acid, relatively low $\mathrm{Fe} 2 \mathrm{O} 3$ content (\%) and $\mathrm{TiO}_{2}$ content (\%) value is desired since the low iron oxide and titanium oxide contents improve the competitiveness of kaolin fraction in the commercial market. However, it was difficult to optimize the two responses under the same conditions because the interest regions of them were different. So, the best possible goal for each response was determined by Numerical optimization of the overall desirability function using mentioned Design-Expert1 Software. To achieve the maximum desirability, parameters were set as minimize without a target. The obtained predicted optimal values for the independent variables were as follows: $X_{1}$ : Sulfuric acid concentration $=4.99252$ molar, $X_{2}$ : Oxalic acid concentration $=10.0083 \mathrm{~g} / \mathrm{l}$ and $\mathrm{X}_{3}$ : time $=2.28294 \mathrm{hrs}$. to achieve minimum iron oxide content of $0.201492 \%$ and titanium oxide content of $0.183944 \%$ as shown in Figure (12) with overall desirability of 1.00 .

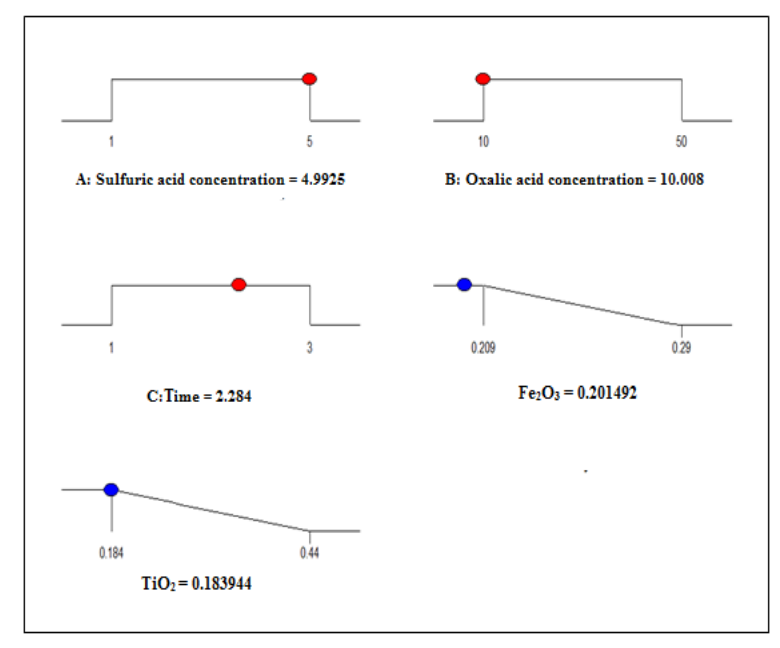

Figure (12): Optimized process condition.

The validity of this prediction was examined by performing an experiment using the predicted optimal values. The iron and titanium contents obtained in this experiment were 0.209 and $0.184 \%$ as shown in Table (9). Overall, the experimental values were in close agreement with the obtained calculated values from the models. As a result, RSM proved to be an effective method to optimize the experimental conditions under consideration. 
PROCESSING OF WADI QENA KAOLINITIC WHITE SANDS BY SELECTIVE DISPERSION AND LEACHING FOR INDUSTRIAL USES

Table (9): Model Validation.

\begin{tabular}{|c|c|c|c|c|c|c|}
\hline $\begin{array}{c}\text { Sulfuric } \\
\text { concentration } \\
(\text { molar })\end{array}$ & $\begin{array}{c}\text { Oxalic } \\
\text { concentration } \\
(\mathrm{g} / \mathrm{l})\end{array}$ & $\begin{array}{c}\text { Time } \\
(\mathrm{hr})\end{array}$ & \multicolumn{2}{|c|}{ Fe2O3\% } & \multicolumn{2}{c|}{ TiO2 \% } \\
\hline \multirow{2}{*}{4.99252} & 10.0083 & 2.28294 & Predicted & Experimental & Predicted & Experimental \\
\cline { 4 - 7 } & & & 0.201492 & 0.209 & 0.183944 & 0.184 \\
\hline
\end{tabular}

Table (10) shows ten experiments of the predicted optimal values for the independent variables taken by mentioned Design-Expert1 Software to achieve low iron and alumina contents.

Table (10) shows experiments of the predicted optimal values for the independent variables

\begin{tabular}{|c|c|c|c|c|l|}
\hline NO & $\begin{array}{c}\text { Sulfuric acid } \\
\text { concentration }(\mathbf{g} / \mathbf{l})\end{array}$ & $\begin{array}{c}\text { Oxalic acid } \\
\text { concentration } \\
\mathbf{( g / l})\end{array}$ & $\begin{array}{c}\text { Time } \\
\mathbf{( h r})\end{array}$ & $\mathbf{F e}_{\mathbf{2}} \mathbf{O}_{\mathbf{3}} \mathbf{\%}$ & $\mathbf{T i O}_{\mathbf{2}} \%$ \\
\hline 1 & 4.99375 & 10.4999 & 2.17292 & 0.206884 & 0.18336 \\
\hline 2 & 4.99502 & 10.8905 & 1.80831 & 0.207798 & 0.181953 \\
\hline 3 & 4.99252 & 10.0083 & 2.28294 & 0.201492 & 0.183944 \\
\hline 4 & 4.96387 & 10.6353 & 1.84284 & 0.208003 & 0.181307 \\
\hline 5 & 4.99274 & 10.1879 & 1.86469 & 0.205447 & 0.177991 \\
\hline 6 & 4.91382 & 10.3471 & 2.02661 & 0.208272 & 0.180831 \\
\hline 7 & 5 & 10 & 2 & 0.204375 & 0.176 \\
\hline 8 & 4.96081 & 10.4757 & 1.77051 & 0.207175 & 0.18286 \\
\hline 9 & 4.98599 & 10.0215 & 2.20465 & 0.203026 & 0.18077 \\
\hline 10 & 4.95219 & 10.9319 & 2.07905 & 0.208252 & 0.181982 \\
\hline
\end{tabular}

\section{CONCLUSIONS}

The aim of this study was the removal of impurities from $-25 \mu \mathrm{m}$ kaolin obtained from the attrition of wadi-Qena Kaolinitic white sand ore by dispersion and leaching. In this regard, two group of experiments were made. The first group includes selective dispersion and flocculation experiments. The results showed that a kaolin product containing $0.542 \% \mathrm{Fe} 2 \mathrm{O} 3$ and $0.924 \mathrm{TiO} 2$ were obtained and physical properties improved such as brightness increased from 76.45 to 81.32 , Iso-brightness increased from 84.15 to 86.85 , whiteness increased from 91.73 to 93.18 , redness decreased from 0.22 to 0.17 and yellowness decreased from 5.84 to 3.96 . Secondly in an attempt to decrease the $\mathrm{Fe} 2 \mathrm{O} 3 \%$ and $\mathrm{TiO} 2 \%$ contents in -25 kaolin product leaching processes was carried out. Also Process optimization of the experimental conditions (sulfuric acid concentration, oxalic acid concentration and time) was carried out by means of Box-Behnken design (BBD) of Response surface methodology (RSM). Two responses (iron oxide and titanium oxide content) were chosen to be the responses. Quadratic model which expressed the functional relationship between the two responses and the three independent variables were obtained by ANOVA. The correlation coefficients (R2) of 0.9680 and 0.9611 for iron oxide \% and titanium oxide \% showed the good fit of the experimental data to the model. It was found that iron oxide response was in significantly influenced by interaction between variables and titanium oxide response was significantly influenced by interaction between sulfuric acid and oxalic acid, sulfuric acid and time and insignificantly affected by interaction between oxalic acid and time. Simultaneous optimization was performed on the basis of the desirability function to determine the optimal conditions of variables for desired iron oxide and titanium oxide contents. The best minimum iron oxide \% (0.201492) and minimum titanium oxide content \% (0.183944) were found at optimum process conditions. These conditions are, sulfuric acid concentration (4.99252 molar), oxalic acid concentration $(10.0083 \mathrm{~g} / \mathrm{l})$ and time $(2.28294 \mathrm{hr})$. These optimum values of 
$\mathrm{Fe} 2 \mathrm{O} 3 \%$ and $\mathrm{TiO} 2 \%$ were further validated by actually performing an experiment at the optimized values of parameters and were found in good agreement with the values predicted by models.

\section{REFERENCE}

[1] B. S. Badmus, O. B. Olatinsu, Geophysical evaluation and chemical analysis of kaolin clay deposit of Lakiri village, southwestern Nigeria, International Journal of Physical Sciences Vol. 4 (10) (2009) 592-606.

[2] J.P. Pruett, JR.M. Pickering, kaolin, Industrial Minerals and Rocks, 7th Edition, (2006) 383-399.

[3] A.A. Aja, J.G. Randy, Physical Properties of Kaolin Used In Soap Production in Nigeria, the International Journal of Engineering and Science (IJES), Vol. 2, Issue.10, (2013) 10-15.

[4] M.S. Prasad, K.J. Reid, H.H. Murray, Kaolin processing, properties and applications, Elsevier Science Publishers B.V., Amsterdam, Applied Clay Science, Vol. 6, (1991) 87-119.

[5] A. B. Luz, A. Middea, Purification of kaolin by selective flocculation, Center for Mineral Technology-CETEM, Ilha da Cidade Universitária 21941-590-Rio de Janeiro, RJ, Brasil, (2004) 243-253.

[6] A. Tuncuk, S. Ciftlik, A. Akcil, Factorial experiments for iron removal from kaolin by using single and two-step leaching with sulfuric acid, Hydrometallurgy 134-135 (2013) 80-86.

[7] S. Ubaldini, L. Piga, P. Fornari, R. Massidda, Removal of iron from quartz: a study by column leaching using a complete factorial design. Hydrometallurgy 40, (1996)369-379.

[8] F. Vegliò, B. Passariello, M. Barbaro, P. Plescia, A.M. Marabini, Drum leaching tests in iron removal from quartz using oxalic and sulphuric acids. Int. J. Miner. Process. 54 (1998)183-200.

[9] S.S. EL-Wekeil, F.S. Gaafar, Characterization and economic potential of the white sandstones of the Naqus Formation in Wadi-Qena, northern Eastern Desert, Egypt, Middle East Journal of Applied Sciences, (2014) 392-408.

[10] S. Gaafar, Study of glass sand in the Wadi-Qena North Eastern Desert - Egypt, The Egyptian geological survey, report, (2012).

[11] R. Gottipati, S. Mishra, Process optimization of adsorption of Cr (VI) on activated carbons prepared from plant precursors by a two-level full factorial design, Chem. Eng. J. 160 (2010) 99-107.

[12] M. Vaez, A. Zarringhalam Moghaddam, S. Alijani, Optimization and modeling of photocatalytic degradation of azo dye using a response surface methodology (RSM) based on the central composite design with immobilized titania nanoparticles, Ind. Eng. Chem. Res. 51 (2012) 41994207.

[13] L. Huiping, Z. Guoqun, N. Shanting, L. Yiguo, Technologic parameter optimization of gas quenching process using response surface method, Comput. Mater.Sci.38 (2007) 561-570.

[14] F.B. Shahri, A. Niazi, Synthesis of modified maghemite nanoparticles and its application for removal of Acridine Orange from aqueous solutions by using Box-Behnken design, Journal of Magnetism and Magnetic Materials 396(2015) 318-326.

[15] M. Aslam, M. Aqil, A. Ahad, A. K. Najmi, Y. Sultana, A. Ali, Application of Box-Behnken design for preparation of glibenclamide loaded lipid-based nanoparticles: Optimization, in vitro skin permeation, drug release and in vivo pharmacokinetic study, Journal of Molecular Liquids 219 (2016) 897-908

[16] M. Taran, E. Aghaie, Designing and optimization of separation process of iron impurities from kaolin by oxalic acid in bench-scale stirred-tank reactor, Applied Clay Science 107 (2015) $109-116$.

[17] S. Widiastuti, E. S. Irfan, A. C. Ceferino, P. Miguel, G. Barrosocarmelo, Multiresponse optimization of a UPLC method for the simultaneous determination of tryptophan and 15 tryptophan-derived compounds using a Box-Behnken design with a desirability function, Food Chemistry 225 (2017) $1-9$.

[18] Q. Pengpeng, C. Mingcan, K. Kyounglim, P. Beomguk, S. Yonggyu, K. Eunkyung, M. Jang, K.J. Khim, Application of Box-Behnken design with response surface methodology for modeling and optimizing ultrasonic oxidation of arsenite with $\mathrm{H}_{2} \mathrm{O}_{2}$, Cent. Eur. J. Chem, (2014) 164-172. 
[19] P. Seher, D. Kerim, Optimization of enzymatic \& ultrasonic bio-scouring of linen fabrics by aid of Box-Behnken Experimental Design, Journal of Cleaner Production 135 (2016) 1179-1188.

[20] M.M. Kulkarni, G.N. Jadhav, Reduction of Titanoferrous Impurities from Kaolin by Selective Adsorption of Flocculating Agents, International Journal of Scientific \& Engineering Research, Volume 7, Issue 2, ISSN 2229-5518, (2016) 105-111.

[21] D. Shilpi, M. Susmita, Box-Behnken statistical design to optimize preparation of activated carbon from Limonia acidissima shell with desirability approach, Journal of Environmental Chemical Engineering 5 (2017) 588-600.

[22] H. Zeng, P. Zhu, S. Xu, M. Liao, Z. Zhang, X. Liu, J. Du, Preparation of ultra fi ne nanoparticles under supergravity field and their flame-Retardant properties, Ind. Eng. Chem. Res. 53 (48) (2014) 18380-18389.

[23] A. Talib, F. Salam, N. Yusof, S. Ahmad, Y. Sulaiman, Modeling and optimization of electrode modified with poly (3, 4-ethylenedioxythiophene)/graphene oxide composite by response surface methodology/Box-Behnken design approach, Journal of Electroanalytical Chemistry 787 (2017) $1-10$

[24] A.L. Ahmad, S. Ismail, S. Bhatia, Optimization of coagulation-flocculation process for palm oil mill effluent using response surface methodology, Environ. Sci. Technol. 39 (2005) 2828-2834.

[25] F. Abnisa, W.M.A. Wan Daud, J.N. Sahu, Optimization and characterization studies on bio-oil production from palm shell by pyrolysis using response surface methodology, Biomass Bioenergy 35 (2011) 3604-3616.

[26] M. Balasubramanian, Application of Box-Behnken design for fabrication of titanium alloy and 304 stainless steel joints with silver interlayer by diffusion bonding, Materials and Design 77 (2015) 161-169. 